\title{
OBRAZ INÉHO V PREDNEJ STRÁŽI B. PRUSA
}

\author{
The Image of the Others in Predná stráž by B. Prus
}

Keywords: stereotype, imagology, Germans, Jews, cliché, Prus, Predná stráž

Contact: Prešovská univerzita v Prešove; mario.veverka@smail.unipo.sk

\section{Úvod}

Predná stráž patrí medzi najvýznamnejšie románové diela B. Prusa. Ide o Prusov prvý román (Bachórz 2004: 355), čo však neuberá ani na jeho dôležitosti, ani na umeleckej hodnote. Fabula Placówki osciluje okolo niekol'kých centrálnych motívov, z ktorých sa na prvý plán vysúva najmä život rol'níka a jeho spätost's rodnou zemou (Borkowska 1999: 83-84), o ktorú v diele bojuje. Je to motív ústredný, avšak nie ojedinelý. Pozadie sedliackej každodennosti lemujú a prekrývajú rôzne skutočnosti a témy, ktorými Prus demonštruje a vykresluje dobové problémy. Okrem života jednej rodiny a jej problémov sú v diele zachytené inter- a intraetnické vzt'ahy pol’skej spoločnosti, problematika demokratizácie pol'ského sedliactva, industrializácia pol'ského vidieka, etc.

Hlavným protagonistom je Jozef Šlimak a jeho rodina. Prus nám v príbehu predstavuje život Šlimakovcov, akoby prototypu rol’níckej rodiny. Stretávame sa tak s každodennou rutinou protagonistov. Ich život a denné činnosti sú úzko späté s rodnou zemou, predstavujúcou pre rol'níka posvätné miesto. Zem, ktorá prechádza z pokolenia na pokolenie má nielen svoju živitel'skú funkciu, ale hrá aj rolu symbolickú. Šlimak vníma svoju „chudobu“ ako miesto odpočinku jeho otcov a predkov. Prus však mikrokosmos Šlimakovcov neuzatvára a neoddeluje od okolia. Autor naň necháva vplývat' rôzne externé faktory a udalosti (napr. predaj šl'achtického dvora a jeho majetku Nemcom). Sedliacka rodina tak prichádza do kontaktu aj s d’alšími protagonistami a funguje na pozadí širšieho spoločenstva, na ktorom následne Prus rozvíja problémy späté s pol'skou dedinou, nemeckými kolonistami, etc. Okolie Šlimákovcov tvorí dedina, obývaná pol'skými hospodármi, šlachtický dvor a neskôr nemecká kolónia. V̌setky štyri miesta, vrátane Šlimakovej „chudoby“, sa spájajú do štúdie o pol’skom vidieku, zaplnenom rôznymi dobovými problémami a výzvami. 
Prus vo svojom románe rozpracúva a poukazuje na rôzne problémy, spojené s dobovou realitou pol'ského vidieka. Predostiera na príklad zlyhanie šl'achtického dvora, ako patronátu sedliactva a predstavitel'a šl'achticko-sedliackych vzt'ahov. Mladá šlachtičná sa na vidieku nudí a sníva len o tom, ako s mužom majetok predajú a odídu bývat' do Varšavy. Jej interakcia s jednoduchým obyvatel'stvom je obmedzená na pokusy o osvetu, ktoré by sme však skôr mohli vnímat’ ako paródiu a nie reálnu pomoc. Šl'achtica hospodári opisujú ako dobrého a múdreho človeka, ktorému však nezáleží na l'ude a ani na svojom rodinnom majetku. Najkomickejšou postavou je práve mladý švagor šl'achtica, ktorého Szweykovskí označuje za „,paródiu apoštola demokratizmu“ (Szweykowski 1971: 245). Predajom svojej rodinnej zeme šl'achta úplne zlyháva vo svojom poslaní pomáhat' l'udu. Jej rolu Prus vidí už iba v spomínaní na minulé časy, predstavené v symbolickom maškarnom sprievode. Obdobné zlyhanie autor pripisuje postave kn̆aza v dedine, ktorý je viac šl'achticom ako duchovným pastierom. Kn̆az pôsobil tak honosne, že l'udia si aj Boha predstavovali ako „vel'kého pána“. Oči slečny Teofilovej sú duchovnému prednejšie ako hl'adanie si cesty k l’udu. Hoci na konci príbehu Šlimakovi pomôže, nedôjde k metamorfóze jeho charakteru a po udelenej pomoci uteká hrat' karty na šl'achtický dvor.

Majetok po šl'achticovi teda nakoniec kupuje Žid pre nemeckých kolonistov. Príchod Židov a Nemcov narúša život pol'skej dediny, najmä však rodiny Šlimakovcov. Kolonisti a postupná industrializácia sú akoby spúšt'ačmi nešt’astia, ktoré rodinu postretlo. Stavba železnice, zárobky Šlimaka a neochota predat' svoju zem Nemcom rozbieha ret'az konfliktov, ktoré hlboko zasiahnu život tejto jednoduchej rodiny. Prvotné úspechy čoskoro zatienia osobné tragédie hospodára (smrt' syna, ženy, pomocníka, nezamestnanost', požiar hospodárstva etc.). Straty nešt’astný sedliak, izolovaný Poliakmi i Nemcami, pripisuje najmä kolonistom a ich príchodu. Práve na tejto izolácii Prus podl'a nás demonštruje nejednotnost' a nesúdržnost' pol'ských rol'níkov, ktorá je citel'ná aj v samotnom príbehu. Jednoduchý rol'ník však aj napriek nepriazni osudu a vel'kým osobným i majetkovým stratám odoláva a postupne sa dvíha hore. Vd'aka Šlimakovi a jeho tvrdohlavosti Nemci opúšt'ajú nadobudnutú zem, ktorú od nich kupujú naspät' pol'skí rol'níci. Intervencia kňaza nakoniec zaistí, že dedinčania príjmu opusteného Šlimaka spät' medzi seba a postavia ho opät' na nohy.

\section{Analýza obrazu iného}

Predná stráž nám zároveň ponúka náhl’ad do interetnických vzt'ahov a kontaktov, ktoré Prus predostiera aj v Bábke alebo Faraónovi. Autor síce nepredstavuje tak širokú paletu etnických obrazov, ako vo vyššie spomenutých dielach, ale jeho „cudzi““ protagonisti 
majú vo fabuly svoju neodmyslitel'nú úlohu a dotvárajú kolorit dobovej reality. Rodine Šlimakovcov a rôznorodému pol'skému obyvatel'stvu, ako dominantnej skupine „My“, tak v príbehu asistujú Židia a Nemci, zastupujúci skupiny „Oni““.

Pri analýze sa budeme opierat' najmä o teóriu imagológie, ktorá skúma obrazy samých seba (autoobraz) a obrazy iných (heteroobraz) v literárnych i mimoliterárnych textoch. Náš krátky príspevok si kladie za úlohu preskúmat' a zinterpretovat' vyobrazenie etnických skupín a ich protagonistov, zohl'adňujúc ich fyziognomické a charakterové vlastnosti. Našu pozornost' upriamime aj na kontakty cudzincov s pol'skou skupinou „My“. Bude nás zaujímat’ aj skutočnost', do akej miery sa Prus pri vykresl'ovaní inonárordných protagonistov opieral o národné stereotypy a klišé, prítomné v európskej a pol’skej literárnej a kultúrnej pamäti.

\section{Obraz Židov}

Židia tvoria v Prednej stráži neodlúčitel'nú súčast' deja a to aj napriek tomu, že z ich radov nepochádzajú žiadny hlavný protagonisti. Ich obsadenie sa síce ohraničuje iba na vedl'ajšie postavy, ale ich interakcia silne otriasa dejovou líniou a ovplyvňuje život hlavného hrdinu.

Najširšie charakterizovanou postavou je Žid Josel, majitel' a prevádzkovatel' miestnej krčmy. Josel je nielen krčmárom, ale v príbehu zohráva aj úlohu „hlavy dediny“, či vodcu skupiny zlodejov alebo úžerníka. Je to práve on, kto stojí za mnohými nekalost’ami, ktoré sa v príbehu dejú.

Hirszgold je bohatý židovský kupec z Varšavy, ktorý je charakterizovaný len vel'mi stroho a v príbehu sa s ním priamo stretávame iba raz. Jeho vystupovanie nám prezrádza, že je úzko spätý s obchodmi Josela a rovnako sa pričiňuje na nešt’astí pol'ských rol'níkov.

Posledný a taktiež skromne charakterizovaný židovský protagonista v diele je Jojna Niedoperz. Tento skromný a jednoduchý podomový predajca a pracovník predstavuje jedinú pozitívnu židovský postavu v diele. Jeho zásah a duchaprítomnost' na konci príbehu zachráni hlavného protagonistu od istej smrti. 


\section{Krčmár Josel}

Za výčapným pultom stál Josel v špinavom vlnenom kaftane s čiernymi pásmi. Mal špicatý nos, špicatú bradu, špicaté pajesy, špicaté lakte a špicatú čiapočku, a v očiach taktiež čosi bodavého (Prus 2014: 61). ${ }^{1}$

Opis krčmára Josela je už na prvý pohl'ad vel'mi negatívny a stereotypný. Narátor podtrháva inakost' postavy pomocou jej výzoru, pričom sa pri jej opise nevyhýba výslovne negatívnym prvkom. Našu pozornost' zaujala znížená úroveň hygieny prezentovaná „špinavým kaftanom“. Nečistotu u židovských protagonistov vnímame ako stereotypné zobrazenie. Obdobnú charakteristiku Prus využíva aj v Bábke, v ktorej rovnako poukazuje na zníženú hygienu židovských postáv. Negatívne vyznieva aj charakteristika výzoru krčmára. Jeho špicatost' dodáva jeho postave priam karikatúrne kontúry. Zaujali nás aj oči Josela, ktoré sú rovnako „bodavé“ ako zvyšok tela a podčiarkujú jeho negatívnu auru, vyžarujúcu z celej tejto postavy. Stereotypne pôsobí aj samotná profesia Josela.

Charakterové vlastnosti krčmára sú rovnako stereotypné a negatívne, ako jeho vonkajšia charakteristika:

Krčmár mu vyčital, že Židkom kazí ceny, predávajúc všetko lacnejšie (Prus 2014: 53) alebo - Svedkov - povedal - teda nemám a preto som od teba doteraz peniaze nepýtal. Ale ak mi tu odprisaháš, do očí, pred l'ud'mi, že si vtedy nebozkával a neprosíkal o pôżičku, tak - ja ti teda tých mojich sedem zlotých odpustím. Hanba-dodal krčmár a odpl'ul si-aby paholok od tak poriadneho hospodára okrádal úbohých Židkov! ... Ja vám, Owczarz, odpustím, ale od tejto chvile nikdy nevstupujte do mojej krčmy, lebo ja sa za vás musím hanbit' (Prus 2014: 54).

Fragmenty z knihy nám opät' predostierajú sériu stereotypov a negatívnych vlastností uvedeného protagonistu. Josel, ako chamtivý a skúpy Žid, nechce zlacňovat' svoje tovary, ale radšej robí Šlimakovi výčitky. Negatívne pôsobí aj Joselov prehovor voči starému paholkovi Mačkovi, ktorý si k nemu príde rozmenit' peniaze. Krčmár, ktorý „,nikdy nedáva na sekeru“ (Prus 2014: 54), si akoby náhodou spomenie, že mu úbohý Maček dlží peniaze. Vyhrážkami a apelovaním na paholkovo svedomie od neho Josel peniaze dostane. Prešibanost' a bezcharakternost' sú tak d'alšie vlastnosti, ktoré krčmár vykazuje.

Než sa Maček stihol rozhodnút', vodka už bola na stole. Podal ju krčmár hovoriac: - Prečo by nemal vodku ponúknut? On už ponúkol! ... Je to

\footnotetext{
${ }^{1} \mathrm{~V}$ prípade citátov z knihy ide o vlastný preklad.
} 
dobrý sedliak ... - Čo sa dialo neskôr, si Owczarz nepamätal (Prus 2014: $55)$.

Stereotypne pôsobí aj obraz Žida krčmára, ktorý na dedine upíja l’udí pálenkou a získava od nich peniaze. Obdobné židovské stereotypy stretávame aj v slovenskej literatúre (napr. u S. H. Vajanského) (Szabó 2012: 79). Citovaný fragment nám zároveň prezrádza aj moc krčmára v dedine. Váha jeho slova je porovnatel’ná so slovom kňaza, či šl'achtica. Pálenka, nedôvera a nezáujem zo strany kňaza a šl'achty tlačia obyvatel'ov dedinky nad riekou Białkou rovno do Joselovej moci.

- Čože to, chcete kúpit' dedinu od dediča?

Rol'níci sa pozreli na Josela, ktorý sa usmieval. (...)

- Práve, že taký veru nie ... - tvrdohlavo prehlasoval hroziac pästou.

- Kto sa mi nebude páčit', toho ku kúpe nepripustím, a basta! ...

Krčmár sa usmieval (Prus 2014: 61).

Úryvok demonštruje Joselovu vládu nad dianím v dedine. Túto skutočnost' nám potvrdzuje aj jeho úsmev, ktorý ho neprešiel ani po skončení hádky medzi hospodármi a Šlimakom. Vel'avravné pohl'ady hospodárov na Žida a jeho neprestajný úsmev nám zároveň prezrádza, že to on stojí za nenávist'ou a závist'ou, ktorú pocit’ovali obyvatelia dediny voči Šlimakovi. Črtá sa nám tu teda opät’ negatívna a stereotypná charakteristika, vykresl'ujúca Židov ako sprisahancov a osoby, ktoré sa ukrývajú za všetkým zlým. Uvedená charakteristika Josela svedčí aj o jeho pomstychtivosti a závisti:

- Tak vidite, pán hospodár, aké je to zlé Židkom chleba brat?? Ja som kvôli vám prišiel o pät'desiat rubl'ov, vy ste zarobili dvadsatpät', ale ste si zarobili veru aj hnevu $v$ dedine za nejakých sto rublov ... (Prus 2014: 62).

Krčmárov plán je však omnoho prešpekulovanejší, než sa nám na prvý pohl'ad zdá. Rozpútaný hnev dedinčanov, ktorý má sám na svedomí, chce zároveň zneužit’ proti úbohému Šlimakovi:

- Ja - hovoril Josel - by som vás s nimi možno mohol pomerit', ale - čo m̌̆a do toho? Už raz ste mi uškodili a nikdy pre mn̆a dobrého slova nemáte.

- A nepomeríšs - opýtal sa Šlimak.

- Pomeril by som, ale mám svoje podmienky.

$-N o ?$... 
- Vy, Šlimak, mi najskôr vrátite tých pät'desiat rublov, o ktoré som v lete kvôli vám prišiel, a potom ... potom - postavite na svojom pozemku chalupu a prenajmete ju môjmu švagrovi (Prus 2014: 62).

Zaráža nás, akú vel'kú moc Prus Joselovi udelil. Tieň jeho postavy nás sprevádza takmer celým dejom. Žid prakticky stojí takmer za všetkými problémami, ktoré hlavného protagonistu stretávajú. Jeho moc nad dejovou líniou vnímáme aj $\mathrm{v}$ nasledujúcom prehovore jednej z postáv:

Josel hovori, aby dali presne tolko, nie viac, hlavne aby sa neunáhlili, a s istotou si vyhandrkujú svoje... (Prus 2014: 63).

Stará Sobieska pri návšteve Šlimakovcov opisuje „múdre rady“, ktoré krčmár udel'uje hospodárom vo veci kúpi majetku po dedičovi. Zámienku jeho „dobre mierených rád“" nám objasňuje nasledujúca scéna:

- Kol'ko ponúkate? - obrátil sa deprimovaný majitel' na kupca (...)

- Dám Vám dvetisícdvestopätdesiat rublov za hektár, bez vyjednávania odvetil dôrazne kupec - Zajtra dám iba dvetisíc.

- Nikdy! - povedal dedič. - Radšej predám rolnikom.

- Rolníci Vám dajú tisícpätsto rublov, a najviac dajú - takých tisicosemsto (Prus 2014: 74).

Rozhovor medzi Židom Hirszgoldom a dedičom nám opät' indikuje, že v kúpe majetkov má opät' prsty Josel. Jeho rady viedli k tomu, že majetok nakoniec nadobudli Židia a nie rol'níci. Dedinčania sa síce rozzúria a krčmára označia za Judáša, mučikrista, zradcu a obrezanca (stereotypy a klišé o Židoch) (Gans, Leerssen 2007: 207), ale aj nad’alej navštevujú jeho krčmu. Bezmocnost' voči židovskému protagonistovi vyjadruje aj Sobieska, ktorá pozná jeho tajomstvá, ale nemôže ich prezradit', aby si tak zabezpečila prísun alkoholu.

Postava krčmára Josela nestratí svoje stereotypné a negatívne kontúry až do konca fabuly. Jeden z posledných úryvkov, v ktorom sa spomína, znie nasledovne:

- Ty vydriduch jeden! ... Hovor, kto t'a na to nahovoril? ...

- Josel predsa ... (Prus 2014: 174).

Konfrontácia zlodejov koní nám odhal'uje, že aj za týmto zlom sa skrýva židovský krčmár. Využíva dlhy mladého Jaška Grzyba a núti ho, aby pre neho kradol kone 
z okolia, čím spôsoby nielen finančné škody, ale dokonca l'udské straty (smrt' paholka a malého diet'at'a). Jeho bezcharakternost' sa umocňuje ešte tým, že úbohému Šlimakovi prichádza robit' výčitky pre smrt' paholka Mačka, ktorý z vel'kej časti zahynul práve Joselovou vinou.

\section{Kupec Hirszgold}

Hirszgold patrí medzi židovských protagonistov, ktorí boli v diele charakterizovaní len stroho. Jeho skromná charakteristika však dotvára obraz Židov v tvorbe Prusa.

Žid vyzliekol drahý kožuch, vzal do ruky čiapku z bobra a posadil sa na kreslo. Bol to sympatický muž s červenými lícami a gaštanovou bradou (...) Vystrel si nohy v lakovaných topánkach a hl'adiac do plameňa sviece čakal a premýślal (Prus 2014: 73).

Fyziognómia a výzor Hirszgolda stojí v priamom kontraste s Joselom. Kupec je čistý, bohato a módne oblečený. Takýto opis výrazne narúša stereotyp špinavého Žida v tradičnom chaláte s čapičkou na hlave. Hirszgoldov odev na druhej strane pôsobí snobským a zbohatlíckym dojmom, čo bádame aj v jeho správaní:

- Tu máš zlotý, a ked' mi privedieš sluhu Mateusza, dostaneš druhý zlotý.

Chlapec zastavil a s údivom pozrel na Žida.

- A vy poznáte Mateusza? ... - opýtal sa.

- Spoznám, len ho prived.

O chvil'u sa objavil Mateusz.

- Tu máš rubel' - povedal pocestný - a ked' mi zavoláš tvojho pána, dostaneš d'alší rubel' (Prus 2014: 73) alebo Zavolám Vaše kone, vážený pane - povedal sluha zohnutý po samú zem.

- Netreba - odpovedal kupec. - Môj voz ostal vo Varšave, a tento je tak obyčajný, že by som sa s ním radšej nemal chválit'(Prus 2014: 76).

Hirszgold sa nám d'alej prezentuje ako vel'mi trpezlivý a zádumčivý človek, ktorý v každej vol'nej chvíli premýšl'a. Skutočnost', že Prus obdobné vlastnosti pripisoval aj svojim židovským protagonistom v Bábke, nás privádza k názoru, že ide opät' o židovský stereotyp. Trpezlivo čaká na dediča, ale akonáhle prejdú k predaju majetku, začne sa voči šl'achticovi prejavovat' dost' netrpezlivo. Majetok nakoniec získava nátlakom a kontaktmi s aristokraciou (dedičovi nesie list od otca jeho manželky). Svoju úlohu pri tom zohral aj krčmár Josel, ktorý bohatého kupca evidentne podrobne 
informoval o pomeroch na dvore. Hirszgold sa už d'alej v príbehu objavuje len ako echo vlastného mena, spojeného s kúpenými majetkami.

\section{Jojna Niedoperz}

Posledným židovským protagonistom je skromný potulný pracovník Jojna Niedoperz. Jojna sa v príbehu objavuje až na samom konci, uvedený na scénu narátorom ako ,, anjel Pána, ktorého milosrdný otec posiela l'ud’om v poslednej chvíli“ (Prus 2014: 162). Autor nám Jojnu d’alej vykresl'uje ako ,najstaršieho a najchudobnejšieho Žida v okolí. Všetko robil, so všetkým kupčil, ale nikdy nič nemal. S početnou rodinou býval v odl'ahlej chate, ktorej jeden roh zapadol do zeme, chýbalo štvrt' strechy a voknách, pozabijaných doštičkami a papierom, sa len sem-tam blysla sklená tabul'a" (Prus 2014: 162). Je vidiet', že Jojna svojim spôsobom života výrazne narúša proces stereotypizácie židovských protagonistov. Jeho životný štýl a pomery stoja $\mathrm{v}$ ostrom kontraste ku krčmárovi Joselovi a bohatému kupcovi Hirszgoldovi. Pohl'ad na tragédiu Šlimaka v ňom vyvolá l'útost' a spolupatričnost'. Rozhodne sa mu pomôct', a to aj napriek tomu, že sám potrebuje nájst' prácu, aby mohol nakŕmit’ rodinu.

Žid stál, podoprel si bradu a dlho premýšlal. Nakoniec zamkol stajničku, zobral svoj batoh i palicu a vybral sa, avšak nie za most, do dediny, ale cestou nahor. Empatia neštastníka k cudziemu neštastiu bola taká silná, že v tom momente zabudol aj na vlastné problémy, a myslel len na záchranu Šlimaka (Prus 2014: 164).

Počiatočný neúspech u Grochowského starého Žida neodradí a hladá pomoc na fare, na ktorej si nájde aj prácu. Vd’aka Jojnovmu zásahu dochádza neskôr k záchrane Šlimaka pred smrtou.

Môžeme povedat', že židovskí protagonisti v Prednej stráži nepatria medzi dynamické, a ani plastické postavy. Charakterizuje ich skôr nemennost' a jednoduchost'. Ich identita a charakterové vlastnosti sú najmä stereotypné a negatívne (Josel a Hirszgold). Túto monotónnost' ku koncu príbehu narúša Jojna, ktorým Prus židovský heteroobraz dokresl'uje l’udským rozmerom. Vládu Josela a Hirszgolda, vedenú v zmysle známeho „, divide et impera “, tak vystrieda láskavost' a spolupatričnost' „najchudobnejšieho Žida v okolí“. Autor tak jednoznačne vyvracia mýtus o jednofarebných národoch a etnikách. Jeho intenciou pravdepodobne bolo zdôraznit', že každé etnikum (národ) sa skladá z jednotlivcov, ktorí si nemusia byt' vo všetkom podobný. Príchod anjela Niedoperza na záchranu úbohému Šlimakovi mohlo istým spôsobom dopomôct' $\mathrm{k}$ odideologizovaniu 
vnímania Židov v pol’skej spoločnosti. Nevieme však, či tento krátky akt mesiánizmu dokáže prekryt' negatívny obraz Josela a Hirszgolda, prítomný v celom príbehu. Tiene týchto dvoch „vladárov“ ležia od začiatku nad údolím rieky Białki. Josel najskôr izoluje Šlimaka od zvyšku dediny kvôli ziskom. Jeho negatívny vplyv na dedinčanov sa postaral o to, že opustenému rol’níkovi neprišiel nikto na pomoc ani v čase najväčšej núdze. Vd’aka krčmárovým intrigám neskôr Hirszgold kupuje od dediča majetky a privádza do údolia nemeckých kolonistov. Židovský kupec stojí aj za stavbou železnice, kvôli ktorej kolonisti a Židia klčujú celé údolie. Ich zásah do panenskej pol'skej prírody by tu mohlo znamenat' symbolické ohrozovanie Pol'ska, spolu s jeho dlhoročnými tradíciami. Konflikt s vodcom nemeckých kolonistov dostáva rodinu Šlimakovcov do úplnej izolácie a privádza na pokraj chudoby. Krádež koní, za ktorou sa skrýva opät' Josel, pripravuje hlavného protagonistu takmer o všetko. Nemohli sme si nevšimnút', že všetky uvedené tragédie sú istým spôsobom späté s postavou Hirszgolda a Josela. Ich konanie nám pripomína organizovanú zločineckú skupinu, ktorá sa ukrýva za všetkým zlým. Záverom možno dodat', že Prus tu z nášho uhla pohl'adu svojich židovských protagonistov predstavuje v zmysle príslovia „dobrý sluha, ale zlý pán“. Vedúce Židovské osobnosti, ktoré majú moc, zneužívajú svoj vplyv len pre vlastné dobro a nehl'adia pritom na obete svojich činov. Protikladom Hirszgolda a Josela je Jojna v podobe skromného „sluhu“, ktorý za zlomeným Šlimakom prichádza s pomocnou rukou.

\section{Obraz Nemcov}

Nemeckí kolonisti tvoria neodlúčitel'nú súčast' príbehu. Ich príchod je úzko prepojený s motívom boja o rodnú zem. Nemci sa pod vedením rodiny Hamerovcov usídlujú v doline rieky Białki. Vybudujú si svoju kolóniu, pestujú plodiny, pomáhajú pri stavbe železnice, etc. Zem nadobudli od Žida Hirszgolda, ktorému musia doplatit' zvyšnú čast' peňazí. Starý Hamer teda plánuje stavbu mlyna, ktorý by im mal potrebné peniaze zabezpečit'. Rol'ník Šlimak im však odmietne predat' svoje pozemky, čím znemožní stavbu mlyna. Nemcom sa teda nepodarí získat' potrebné finančné prostriedky včas a nadobudnuté pozemky tak budú musiet' opustit'. Nemeckú spoločnost' zastupuje najmä rodina Hamerovcov, starý učitel' a jeho dcéra.

\section{Hamerovci}

Hamerovci sú vedúcimi osobnost’ami medzi kolonistami. Ich rodina sa skladá z otca (starý Hamer) a jeho dvoch synov (Friz a Wilhelm). Žiadneho člena rodiny však Prus 
bližšie necharakterizuje. Pri analýze sa tak musíme opierat výhradne o prehovory a činy nemeckých protagonistov.

Hamerovcov stretávame už na začiatku príbehu, ešte pred samotnou kolonizáciou: Na ceste stáli dvaja l'udia. Jeden sivý, oholený, v temnomodrom zvrchníku s krátkym pásom a v nemeckej čapici so zavinutými okrajmi - druhý bol mladší, vyrovnaný, so svetlou bradou, v plášti a čiapke (Prus 2014: 19).

Naše prvé stretnutie $\mathrm{s}$ Nemcami $\mathrm{v}$ nás nezanecháva žiadne emócie. Ich fyziognómia je predstavená pomerne neutrálne. Zaráža nás však tón, akým mladý Friz Hamer prehovoril k Šlimakovi:

- To pole je tvoje? - opýtal sa bradatý ostrým tónom (Prus 2014: 19).

V jeho správaní vidíme jednoznačnú aroganciu, ktorou sa táto postava legitimuje takmer celý čas trvania fabuly. Istým protipólom je jeho otec, ktorý Šlimaka oslovuje „hospodár" a rozpráva sa s ním vel’mi zdvorilo. Vysúva sa nám tu tak stereotypný obraz Nemca grobiana s priam necivilizovanými spôsobmi správania, ktorý možno stretnút' aj v iných európskych literaturách (Beller 2007: 160).

Aroganciu a vyhrážky stretávame aj v d’alších dialógoch so Šlimakom:

- Takže nepradáš? - opýtal sa starec.

- Ni. - odvetil Šlimak.

(...) - A ja ti hovorim, že predáš! - zakričal bradáč, silno chytajúc otca za ruku.

$-N i$.

- Predáte, hospodár - zopakoval starý (Prus 2014: 78).

Úryvok poukazuje na brutalitu mladého Friza, ktorý sa správa povýšenecky a egoisticky. Arogantne vystupuje nielen voči Šlimakovi, ale aj voči svojmu otcovi.

Uvideli ho aj oni, pretože sa pri ňom hned' objavil Friz Hamer. Vyzeral ako dozorca.

- Skade si sa ty tu vzal? - naštvane sa opýtal.

- Aj ja som si chcel nájst' robotu.

Nemec sa zamračil.

- Tu nič nezarobíš - povedal. Ked' však videl, že Šlimak sa obzerá a čaká, išiel za zapisovatelom a chvilu sa snim rozprával. Teraz pribehol k rolnikovi zapisovatel' a už z cesty kričal: - Netreba vozy! Netreba ... Aj 
tých máme viac než dost' ... Nemáš tu prečo čakat', lebo iným len cestu blokuješ. Chod' nabok! ... (Prus 2014: 105).

Scéna z miesta stavby železnice opät' potvrdzuje povýšenectvo a aroganciu mladého Nemca. Friz sa po neúspešnom pokuse kúpy Šlimakových pozemkoch snaží úbohého rol’níka donútit', aby sám odišiel. Našej pozornosti pritom neuniká brutalita s akou to chce Nemec docielit'. Znemožňuje Šlimakovi nájst' si prácu a zarobit tak peniaze pre svoju rodinu. Izoluje ho zo všetkých strán. Obviňuje ho z krádeže koní, ktoré ma na svedomí Žid Josel. Zneužíva aj bitku so Šlimakovým synom Jędrkom, ktorú vyvolali Nemci, a žaluje ho na súde. Friz tak pripravuje hospodára aj o posledného syna, ktorého posiela sediet' do kriminálu.

Protagonisti neprekročia tieň vlastnej negativity ani po požiari Šlimakovho domu. Prichádzajú mu síce na pomoc, ale opät' len pod podmienkou, že im predá svoje pozemky.

- A dnes večerom sa u m̌̆a dohodneme.

- Možno aj dnes.

- No, ked' takto - povedal po chvíli Hamer - ja vám čosi poviem. Dám vám teda sedemdesiatpät' rublov za hektár a nedopustím, aby ste tu zahynuli. Vašu ženu odvezieme do kolónie a ubytujeme ju v škole. Tam je teplo. Obaja prezimujete u nás, a ja vám za robotu budem platit ako našim paholkom (Prus 2014: 155-156).

Bezcharakternost' a zákernost' Hamerovcov zdôrazňuje už samotný začiatok vety „,no, ked' takto “. Naznačuje nám, že záleží na Šlimakovi a jeho rozhodnutí, či mu Nemci pomôžu alebo ho nechajú so smrtel'ne chorou manželkou napospas osudu.

\section{Učitel' a jeho dcéra}

Protipólom Hamerovcov je nemecký učitel' a jeho dcéra. Prus nám neodhal'uje ich mená. Celá ich existencia a identita je tak vyhranená jedine vd’aka profesii (učitel') a vzájomným rodinným vzt’ahom (otec a dcéra).

„Bol to chudý a bledý človek, sčervenými vlasmi a takou istou bradou“ (Prus 2014: 86).

Charakteristika starého učitela je neutrálna a jeho príchod na scénu, na ktorú ho dotiahne vlastné dcéra na voze, v nás vzbudzuje l'útost' a istú sympatiu voči starému 
človeku. Opis dcérinej fyziognómie v tejto scéne absentuje. Možno sa však domysliet', že to bola pôvabná dievčina, ked’že učarovala pätnást'ročnému Jędrkovi. Narátor neskôr v príbehu poukazuje na jej „sivé oči““ a „počernú tvár" (Prus 2014: 99).

Výzor učitel'a a jeho dcéry však nie je taký dôležitý ako funkcia, ktorú im Prus medzi kolonistami udelil. Svojim milým správaním, vzdelaním, poctivost’ou a úctou voči Šlimakovi stoja v kontraste k hrubým a pomstychtivým Hamerovcom.

Učitel' si obzrel Staška a kázal matke odíst'. (...) Starý vysunul lavicu, vyzliekol z chlapca premoknutý košel'u, a silou mu vytiahol jazyk. (...) Teraz učitel' vystrel Staškove ruky pozdlž bedier a zdvihol ich dohora, až za hlavu, potom znovu položil k bedrám. Znovu ich zdvihol, znovu pustil. Takto ich zdvíhal a púš́tal, aby pomocou tohto pohybu chlapec začal dýchat' (Prus 2014: 119).

Smrt' Šlimakovho syna vyvolala v starom učitel'ovi lútost'. Starec sa, aj napriek vlastným zdravotným t’ažkostiam, vybral k hospodárovej chalupe a snažil sa chlapca vzkriesit'. Pedagóg v scéne preukazuje nielen svoju láskavost' a starostlivost', ale aj vlastné vedomosti a vzdelanost'. Obraz starostlivého a empatického Nemca v nás vyvoláva aj správanie učitel'ovej dcéry voči Jędrkovi (Prus 2014: 99). Pozitívne zobrazenie uvedených protagonistov podčiarkuje aj skutočnost', že učitel' a jeho dcéra zadarmo učili Šlimakovho syna čítat' a písat', čím vlastnosti Nemcov v Prednej stráži rozšírili o vzdelanost', nezištnost', láskavost' a starostlivost'.

Nemci, predstavení v diele vel'mi staticky a plocho, môžu na nás pôsobit' trojakým dojmom. Jednu stranu predstavujú Hamerovci. Ich arogancia, bezohl'adnost', bezcharakternost' a povýšenost' pôsobia na čitatel'a vel’mi negatívnym dojmom. Svojim vystupovaním a správaním sa zarad’ujú medzi záporné postavy, ktorým chýba akákol'vek dobrá vlastnost'. Jediným pozitívnym prejavom je láska starého Hamera $\mathrm{k}$ jeho synom. Autor však, obdobne ako u Židov, aj do prostredia Nemcov vnáša pozitívny obraz vo forme učitel’a a jeho dcéry. Títo dvaja protagonisti narúšajú proces stereotypizácie a negativizácie obrazu Nemcov práve svojimi dobrými vlastnostami a vystupovaním. Ich strohá charakteristika čiastočne naznačuje, že Prus pravdepodobne tieto postavy vytvoril programovo len pre účely nivelizácie nemeckej spoločnosti (podobne ako v prípade Jojny Niedoperza). Obraz Nemcov nám však nedotvárajú iba samotní protagonisti, ale aj Nemci ako skupina. Ich charakteristiku nám autor predostiera na viacerých miestach $\mathrm{v}$ knihe, pričom apeluje najmä na ich jednotnost' a súdržnost'. Tieto vlastnosti Prus vyzdvihuje úmyselne, aby ich tak postavil do opozície k nejednotnosti a chabej solidarite pol'skej rol'níckej spoločnosti (Szweykowski 1971: 248). Obraz pracovitosti, systematiky a morálky nemeckých kolonistov, opísaný 
v príbehu, možno však zaradit' už medzi nemecké stereotypy (Beller 2007: 162). Stereotypne pôsobí aj obraz Nemca s pivom v ruke, ktorý sa v príbehu taktiež vyskytuje.

\section{Zhrnutie}

Autor nám vo svojom diele predostiera obraz dvoch etnických skupín, ako cudzieho elementu „Oni“" na pozadí pol'skej spoločnosti. Stretávame sa tak s obrazom Židov a Nemcov, ktorí predstavujú dôležitú súčast' fabuly. Prus nám tak umožňuje sledovat' vzt’ahový trojuholník Žid-Nemec-Poliak. Všetci traja sa ponárajú do konfliktu o pol'skú zem, pričom v tomto boji nakoniec vyhrávajú práve pol'skí rol'níci. Obraz Židov je predstavený zvlášt' negatívne a stereotypne. Židovskú chamtivost', lakomost', úžeru, krčmárstvo, pýchu, aroganciu a prefíkanost' cítit' v každej scéne, v ktorej vystupuje Josel alebo Hirszgold. Negatívne na nás pôsobili aj klišé o Židoch, ktoré v nás len umocňovali stereotypné vnímanie tohto etnika (napr. „Niečo je tak skazené, že by to ani Žid nekúpil“ (Prus 2014: 11), „Čo som ja Žid, aby som za pohostenie peniaze pýtal?!“ (Prus 2014: 28), etc. Kompletnej stereotypizácii a negativizácii zabraňuje svojou intervenciou Jojna Niedoperz. Jeho pozitívnu charakteristiku a dobré vlastnosti možno vnímat' ako svetielko nádeje, ktorým Prus poukazuje na rôznorodost' židovskej spoločnosti. Nemcov spisovatel' vykresluje tiež vel'mi negatívne, na čo sme upozorňovali už pri analýze. Obraz zlých, chamtivých a podlých Hamerovcov čiastočne vyvažuje stereotyp pracovitých, usilovných a disciplinovaných Nemcov. Pozitívne heteroobraz Nemca dotvára aj úctivý a láskavý učitel' so svojou dcérou.

Záverom možno povedat', že Prus obidve skupiny nepredstavil svojim čitatel'om práve v najlepšom svetle. Ich negatívne a stereotypné vlastnosti sú prítomné počas celej fabuly. Autor svojim dielom tak mohol dopomôct' $\mathrm{k}$ šíreniu fóbie voči Židom a Nemcom, či upevnit' ich negatívne vnímanie v pol'skej spoločnosti. Tento negatívny proces Prus nakoniec narúša Jojnom, starým učitel’om a jeho dcérou. Tieto postavy vnímame ako pokus o nivelizáciu negatívnych prvkov. Čiernu realitu v obidvoch táboroch (nemeckom a židovskom) tak autor presvieti lúčom l'udskosti, mravnosti, súcitu a nezištnosti. Etnikám tak dodáva tzv. l’udský rozmer, ktorý ich vytrháva z procesu stereotypizácie a negativizácie. Tento rozmer používa Prus aj v Bábke, aby tak poukázal na skutočnost', že žiadne spoločenstvo nie je iba čierne alebo biele. Jeho existencia je pretkaná rôznymi jednotlivcami. Tieto jednotky, teda l'udia, majú svoje svetlé, ale aj temné stránky. Nemožno však na základe jednej charakterovo čiernej osoby prehlásit', že celý národ je iba čierny. Toto osobne vnímame ako možný odkaz Prusa. Autorovi sa nepodarilo vyhnút' stereotypom a ideologickým obrazom. Jeho zdvihnutý prst vo forme pozitívnych postáv však jednoznačne upozorňuje čitatel'ov, aby sa 
nespoliehali len na národné predsudky a stereotypy, pretože v národoch a ich predstavitel'och sa môže ukrývat' viac, ako sa na prvý pohl'ad zdá.

\section{Summary}

In our article we tried to outline the way, in which Prus has created and presented the characters of Jews and Germans, as the representants of the alterity-group. After analyzing Jewish and German protagonists we have realized that the author created them mostly in negative and stereotype way. The characters as innkeeper Josel, merchant Hirszgold, or the Hamers family evince negative and stereotypical signs (stingy Jew, rude German, etc.). On the other way has Prus created the characters of Jojna Niedoperz (Jew) and teacher with his daughter (Germans). These protagonists are destroying partially the chain of stereotypical attributes. We think that these characters were created intentionally to show to readers, that we cannot rely only on stereotypes and to point out that one black character does not guarantee the negativity of whole nation.

\section{Literatúra}

Bachórz, J. Bolesław Prus. In. Skoczek, A. (ed.) Pozytywizm. Historia Literatury Polskiej. Bochnia-Kraków-Warszawa: Wydawnictwo SMS, 2004.

Beller, M. Germans. In: Beller, M., Leerssen, J. (eds.) Imagology. The cultural construction and literary representation of national characters. AmsterdamNew York: Rodopi, 2007, s. 159-165.

Borkowska, G. Pozytywiści i inni. Warszawa: Wydawnictwo Naukowe PWN, 1996.

Gans, E., Leerssen, J. Jews. In: Gans, E., Leerssen, J. (eds.) Imagology. The cultural construction and literary representation of national characters. AmsterdamNew York: Rodopi, 2007, s. 202-207.

Prus, B. Placówka. Kraków: Wydawnictwo Greg, 2014.

Szabó, M. „Duch mlčí, len surové mäso vyvádza“. Protižidovské stereotypy v ideológii Svetozára Hurbana Vajanského. Forum Historiae. 2012 (6/2), s. 68-83.

Szweykowski, Z. „Placówka. Prus contra Prus”. In: Tyszkiewicz, T. BOLESŁAW PRUS. Warszawa: Państwowe Zakłady Wydawnictw Szkolnych, 1971. 